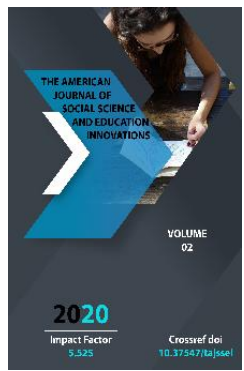

\title{
The Description Of The 'Erabs In Hamiduddin Dariri's
}

\section{Muqaddima}

Alisher Sultonhujaev

Lecturer Of Tashkent State University Of Oriental Studies, Uzbekistan

Copyright: Original content from this work may be used under the terms of the creative commons attributes 4.0 licence.

\section{ABSTRACT}

This article below discusses the description of the grammar rules in Hamiduddin Dariri's Muqaddima.

\section{KEY WORDS}

Nouns; Jarr; Harf; The Arabic 'erab.

\section{INTRODUCTION}

The nouns [as follows]: [The noun] comes in the jarr, i.e. the genitive case, takes the suffix tanwin, can be in the idhaafa [possessive structure], and accepts al - al [definite article].

The sign and features of the verb: requires that the action be in the past or presentfuture tense, or in one of them. 
Character and features of harf: harf is distinguished by the fact that the noun and the verb [word group] are devoid of signs and features. فصل الإعراب على أربعة أوجها: رفع ونصب وخفض

وجزم. فالرفع: هذا زيد ونحوه و علامة الرفع فيه ضمّة الدال. والنصب: رأيت زيداً ونحوه و علامة النصب فيه فتحة الدال. و الخفض: مررت بزيد نحوه و علامة الخفض فيه كسرة الدال. والجزم: لم يفعل ونحوه علامة الجزم فيه سكون اللاح, قال الله تعالى: ولم يجعل له له عوجاً.

There are four types of change in e'rab, i.e. flexion: raf' [, i.e., nominative case], nasb [, i.e., accusative case], jarr [, i.e., the genitive case], jazm [i.e. sukoon (conditional tense form of the verb)].

An example of nominative case: - هذا زيد - This is Zayd. The sign of nominative case is the damma in the letter [د, the last d] of the word زيد.

An example of accusative case: - رايت زيد - I saw Zayd. The sign of accusative case is the fatha in the last letter of the word [د, the last d].

An example of genitive case: مررت بزيليد I passed Zayd and so on. The sign of the genitive case is kasra in the last letter of the word [بزيدٍ: the last letter د-].

An example of a jazm [occuring in verbs] لم - لم - did not do, and so on. The sign of jazm [, i.e. the conditional tense form] is the sukoon[in the last letter $\mathrm{J}$-] in the verb - يفعل Allahu ta'ala said:و لم يجعل له عوجا.

فصل الرفع و النصب يدخلان على الاسماء والأفعال جميعاً. و الخفض يختص بالاسماء دون الأفعال والجزم يختص بالأفعال دون الأسماء. فليس في الأسماء جزم و لا في الأفعال خفض. 
The nasb and raf' cases of words occur in both nouns and verbs.Jarr [i.e.kasra] is specific only to nouns, not to verbs. Jazm [i.e.sukun (conditional tense form of a verb)] is specific only to verbs, and this is not the case in nouns. So, there is no sukoon in nouns and no kasra in verbs.

فصل ليس يعرب من الكلام كله الا الاسم المتمكن والفعل المضار ع. فالاسم المتمكن نحو: زيد، فرس، حجر و نحوه. والفعل المضار ع نحو: يضرب ويذهب ويكتب [و يعمل و مااثبهه]. وسائر الكلام مبني لا يتغير آخره بدخول العو امل [في اوله] عليه نحو: ضرب وكيف وحيث [و أين ونحن ومذ وعن] ومنذ ومن وهئو لاء و وأمس [و من و هل و بل و قد ومس وما اشبهـها.

In Arabic, only the noun(ism) [words in a group of words] that is changed by conjunctions is flexed, and the verb mudhoore [[that is, the present-future tense form] is changed in the infinitive.

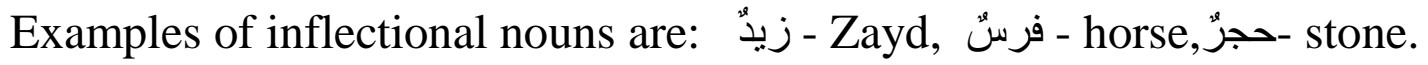

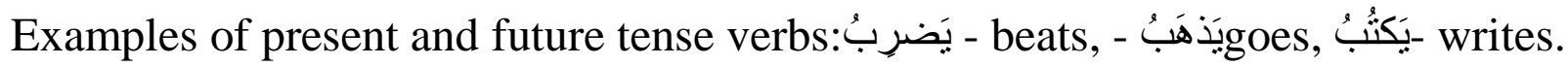

The rest of the words [are] factors, [i.e. prepositions, etc.] that do not affect, do not

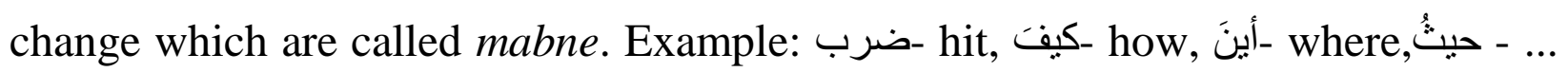

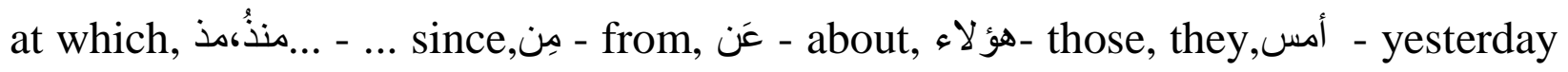
and so on.

فصل الاعراب يلزم آخر الكلمة دون أولها وأوسطها. فالاسم ينون والفعل لا ينون والاسم يضاف والفعل لا

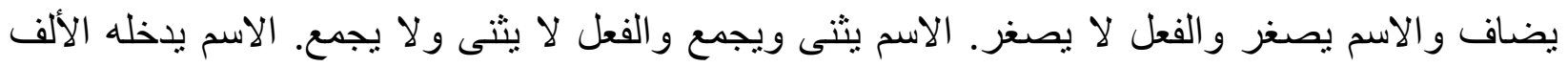

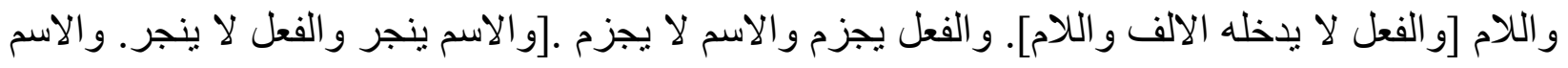

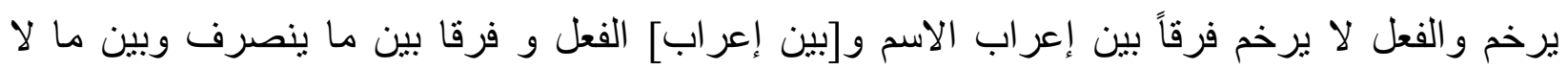
ينصرف. 
The Arabic 'erab[i.e., change in inflection] does not occur at the beginning of a word or at the middle, but at the end.The noun is given a tanwin, and the verb is not. The noun can be mudhaaf [, i.e."the thing annexed"], the verb may not be mudaaf [, i.e."the thing annexed"].The noun comes in decreased form (tasgheer), the verb does not come in decreased form.The dual and the plural are formed from the noun, but not from the verb. The noun takes the definite article, the verb does not.The verb is jazm [, i.e., sukoon (in the form of a conditional tense)], the noun is not in such case.The noun can be in jarr [, i.e. in the genitive case], there is no such case in the verb. The noun can be shortened but the verb cannot be shortened.These are the inflectional differences of nouns and verbs, and the differences between variable and non-variable words in conjunctions.

فصل و إذا ثنيت الاسم المرفوع زدت في آخره ألفاً ونوناً كقولك: جاءني الزيدان وعلامة الرفع فيه الألف

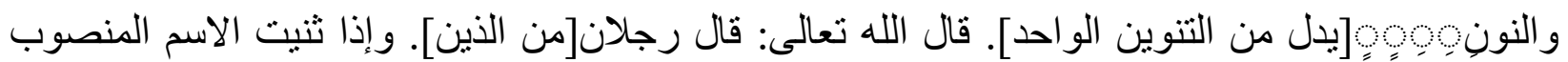
او المجرور زدت في آخره ياءً ونوناً وفتحت ما قبل الياء كقولك: رأيت الزيدين ومررت بزيدين، علامة النصب و الجر فيهما الياء، قال الله تعالى في النصب: و كان أبو اهؤمنين وفي الخفض: كانتا تحت عبدين من عبادنا صالحين.

To make a binary number from the noun in the general agreement, you add ان - alif and nun at the end of the word. For example: جاءنى الزيدان - Two Zayds came to me. The alif and nun in the word زيدال : -رجلان (Al-Maidah, 23).

In order to make a binary number from a noun in genitive and accusative cases, you add a yay and nun at the end of the word and give the fatha to the letter before 
the yoy. For example: رأيت الزيدين - I saw two Zayds. مررت بالزيدين - I passed by two Zayds.

In these two examples, the sign of accusative and genitive cases is the yoy. The word فو أمنين (Al-Kahf, 80) is in accusative case,

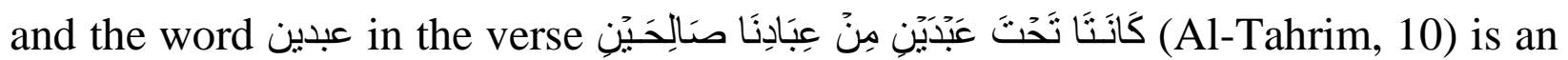
example of genitive case.

فصل و إذا جمعت الاسم المرفوع زدت في آخره واواً ونوناً وضمت ما قبل الواو كقولك: هؤلاء الزيدون و علامة الرفع فيه الواو ، قال الله تعالى: [لا يتخذ المؤمنون الكافرين أولياء].

If you want to make a plural number from the noun in the nominative case, you add wow and nun at the end of the word and give a damma to the letter before wow.Example: هؤلاء الزيدون - They are Zayds. In this example, the raf'symbol is

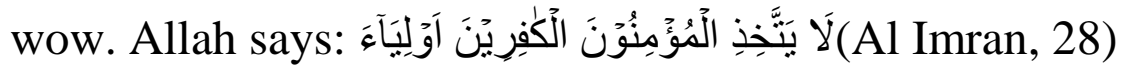

فصل و إذا جمعت الاسم المنصوب أو المجرور زدت في آخره ياءً ونوناً وكسرت ما قبل الياء كقولك: رأيت و علامة الجر و النصب فيهمالياء، قال الله تعالى: في الخفض كان بالمؤمنين ]ومررت بالزيدين[الزيدين رحيماو قال [في النصب] إن المسلمين و المسلمات

To make a plural number from the noun in accusative and genitive cases, you add a yoy and nun at the end of the word and give a kasra to the letter before the yoy.Example: رأيت الزيدِينَ - I saw the Zayds. مررت بالزيدِينَ - I passed by the Zayds.In these two examples, the sign of accusative and genitive cases is the yoy. Allaah

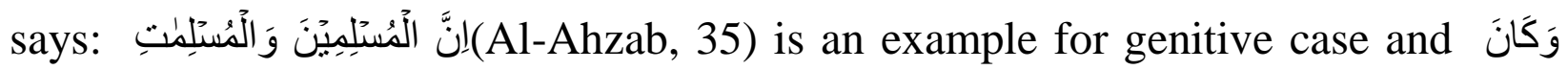

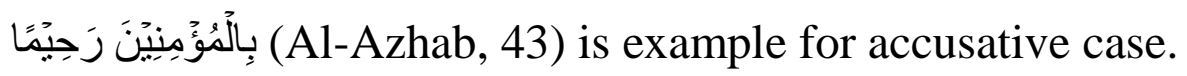


فصل و نون التنية مكسورة ابداً ونون جمع السلامة مفتوحة ابداً. و هما تسقطان عند الإضافة كقوللك: غلاماك وصالحوك [و كان في الأصل غلامان و صالحون] [وبنوك] [فحذفت النون عند الإضافة]، قال الله تعالى: يا بني اسر ائيل. وكان في الأصل بنين فحذفت النون من بنين للإضافة،[قال الله تبارك و تعالي في التثنية: بل يداه مبسوطتان و في الجمع: انا كاثشفون الغداب للك]. و التنوين أيضاً تسقط عندالاضافة ومع الألف واللام كقولك: هذا غلامك و الغلام، قال الله تعالى: [إنِّي عبد الله، قال الله تعالى: والبلد الطيب. ويثبت التنوين بسقوط الألف واللام، قال الله تعالى: اجعل] هذا بلداً آمناً [و قال هذا البلد آمناً، تسقط التتوين بثبوت الألف و واللام].

In nouns, the nun of the binary number always takes kasra, and the nun of the correct plural takes fatha. Both nuns fall in idhaafa. Example: غلاماك - Your two servants (teenager, waiter), صالحوك - Your righteous (noble, good), بنوك - your

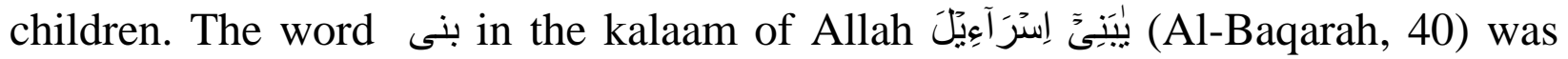
actually بنين, and نn -nun was dropped because it was idhaafa. In idhaafa, tanwin falls from a word that begins with the article [mudhaaf] and al definite article.

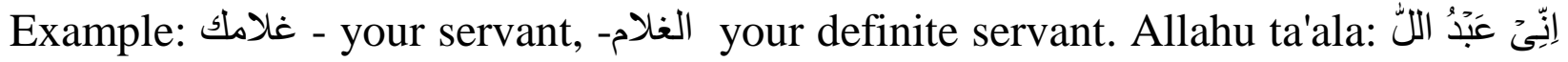

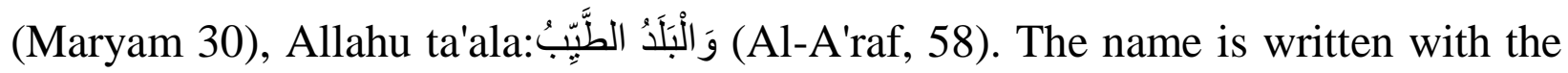
suffix tanwin if it does not take definite article. Allahu ta'ala: رَبِّ اجُعَلْ هُذَا بَلَدًا أِْنًا Baqarah, 126).

\section{REFERENCES}

1. Belova A.G. The syntax of written texts of the Arabic language. - Moscow: Nauka, 1985. - 126 p.

2. Belova A.G. The problem of Arabic linguistics (1960-1973), in collection: Semitic languages, in 3. -Moscow, 1976 
3. Nosirova M. A. Mahmud Zamakhshari's treatise "Al-unmuzaj fi-n-nahv". Tashkent: TDShI, 2005. -186p.

4. Nosirova M. Arabic Linguistics in Movarounnahr. Philological issues. University of World Languages. 2011. № 4. -P.33-37

5. Qosimova S.S. Basic information from classical Arabic grammar. -T..2011.88b 